\title{
Survival of Escherichia coli O157:H7 and Staphylococcus aureus during the fermentation and storage of kefir
}

\author{
Merih KIVANC ${ }^{1 *}$, Evrim YAPICI ${ }^{1}$
}

\begin{abstract}
The survival of Escherichia coli O157: H7 and Staphylococcus aureus, which are foodborne pathogens was investigated during fermentation and storage of kefir. The kefir grains were inoculated with $5 \%$ of the whole fat UHT cow milk and the E. coli O157: $\mathrm{H} 7$ and S. aureus cultures were added separately to give $10^{5} \mathrm{cfu} \mathrm{mL}^{-1}$ and left to incubate at $22^{\circ} \mathrm{C}$ for 24 hours at first stage. During the incubation, the bacteria and yeast counts, $\mathrm{pH}$ and titratable acidity amounts were determined. In the second stage, E. coli O157: $\mathrm{H} 7$ and $S$. aureus cultures were separately added to produce $10^{5} \mathrm{cfu} \mathrm{mL}^{-1}$ of kefir and was stocked at $5{ }^{\circ} \mathrm{C}$ for 3 days. Every day samples were taken and the same tests were done. During fermentation, in all samples the initial while TA was $0.14 \%$, the fermentation was $1.0 \%$ and $1.01 \%$ at the end. The kefir samples were $\mathrm{pH} 4.5$ at the end of the 3 day period of storage. S.aureus was significantly inhibited while E.coli was not inhibited during the fermentation process. During storage, E. coli O157: $\mathrm{H} 7$ and S. aureus were inhibited within 2 days. The kefir has the quality of being a healthy product during fermentation and storage.
\end{abstract}

Keywords: Kefir; E. coli O157:H7; S. aureus; lactic acid bacteria; yeast.

Practical Application: Kefir is a functional fermented dairy product very useful for health. The consumption is quite high. The life span of two important food born microorganisms within this product has been determined. If S. aureus and E. coli contamination occurs after fermentation, the bacteria may be inhibited within 48 hours. This is important for post-fermentation contamination.

\section{Introduction}

Kefir is a fermented milk drink containing a slightly acidic and yeast flavor, naturally carbonated fermented milk with consistently refreshing sweet flavor. It is a milk product prepared with the addition of kefir grains into the milk. Milk is incubated with the kefir grains until lactose is fermented for one day or more at a room temperature. A sour, carbonated and lightly alcoholic beverage is obtained. Kefir grains are composed of a combination of bacteria and yeast in protein, lipid and sugar matrix (Prado et al., 2015). Kefir also contains lactic acid bacteria (LAB) such as Lactobacillus brevis, Lactobacillus plantarum, L. paracasei spp paracasei, L. lactis spp lactis, L. acidophilus, Leuconostoc mesenteroides, and Streptococcus species as well as yeast such as Kluyveromyces marxianus, K. wickerhamii, Saccharomyces cerevisiae, Pichia angusta, P. guilliermondii, Candida glaebosa, C. kefyr and sometimes acetic acid bacteria (Kıvanç \& Yapıcı, 2015; Ünal \& Arslanoğlu, 2013; Schneedorf \& Anfiteatro, 2004; Garrote et al., 2001).

Saccharomyces and Torula yeast can control the harmful yeasts by inhibiting them (Farnworth \& Mainville, 2003). In addition to the beneficial bacteria and yeasts, kefir also contains essential minerals and essential amino acids for the body. It also abundantly contains calcium and magnesium for healthy nervous system. The phosphorus it contains helps to use carbohydrates, fats and proteins for cell growth, maintenance and energy in our bodies. Kefir is rich in vitamin B12, vitamin B1 and vitamin K (Bourrie et al., 2016). Kefir has antimicrobial effect on many Gram positive and Gram negative bacteria and yeast. In vitro tests with kefir cell free extracts, the growth of Staphylococcus aureus, Bacillus cereus, Escherichia coli, Clostridium tyrobutyricum and Listeria monocytogenes was inhibited (Kim et al., 2016; Kıvanç \& Yapic1, 2015). In general, the antimicrobial activity of kefir is caused by bacteriocin-like substances such as lactic acid, lactic acid, hydrogen peroxide, carbon dioxide, diacetyl, acetaldehyde and/or bacteriocin produced by LAB. In addition, kefir has antitumor, anti-inflammatory and hypocholesterolemic effects as well as immunosuppressive properties (Leite et al., 2013; Bourrie et al., 2016).

Many bacteria such as Lactobacillus, Streptococcus, Bacteroides, Escherichia, Bifidobacterium and Clostridium are colonized in the normal gastrointestinal system. Lactobacillus is present in the normal microflora of the gastrointestinal system (Marshall, 1993). It was found that probiotic strains of Lactobacillus had inhibitory effects on the growth of pathogenic bacteria, had acid and gall resistance, adherence to intestinal epithelial cells and positive effects on the host health (Finlay \& Falkow, 1989; Jacobsen et al., 1999). 
Escherichia coli 0157: H7 is one of the most dangerous food pathogens. E. coli O157: H7 that produces Verotoxin can be converted into non-mucosal ischemia, hemorrhagic colitis and hemorrhagic uremic syndrome (HUS), which can be complicated by severe anemia and renal failure. It can cause major worldwide food and water epidemics (Buchanan \& Doyle, 1997; Mead \& Griffin, 1998).

Since $S$. aureus can grow in very large environmental conditions, they can frequently contaminate the animals. Contamination may be originated from raw material or caused during production by people and team and equipment used. Staphylococcal food poisoning is one of the most common diseases of foodborne diseases (Hennekinne et al., 2012). Fermented dairy products are the most common products of $S$. aureus food poisoning (Le Loir et al., 2003). Most strains produce one or more enterotoxins, which are the causes of observed gastrointestinal symptoms (Tamarapu et al., 2001).

In the present study, we tried to evaluate the behavior of E.coli O157: H7 and S. aureus in kefir, which are important for public health during the fermentation and storage of kefir, the fermented dairy product whose benefits has been proven today and determines the life process of pathogenic bacteria in this product.

\section{Materials and methods}

\subsection{Preparation of E. coli 0157:H7 and S. aureus culture}

E. coli O157: H7 and S. aureus used in the study were obtained from the Faculty of Science Microbiology unit of Anadolu University. E. coli O157:H7 was inoculated into Tryptic Soy broth (TSB) and S. aureus was inoculated into Brain Heart Infusion broth (BHI) and incubated for 24 hours at $37{ }^{\circ} \mathrm{C}$ (Chapman, 2000). Then, E. coli 0157:H7 was inoculated onto Sorbitol MacConkey agar with cefixime tellurid (CT-SMAC) and $S$. aureus was inoculated onto egg yolk tellurite Baird Paker agar (BPA) and both were incubated at $35^{\circ} \mathrm{C}$ for 24 hours.; and then colony morphology was examined and Gram staining was performed to check the purity in the microscope (Chapman, 2000; Harrigan \& McCance, 1996).

\subsection{Kefir production}

Kefir grains were obtained from home-made kefir in Eskişehir (Turkey). Kefir grains were washed with sterile distilled water. It was then inoculated into full fat UHT cow milk (3.6\% fat content) and incubated at $22^{\circ} \mathrm{C}$ for 24 hours. After fermentation, the kefir grains were separated from the kefir with the help of a plastic sieve, washed with sterile distilled water and stored in milk at $4{ }^{\circ} \mathrm{C}$. The study was conducted in two stages: Stage I includes the fermentation process and Stage II contains the storage process. In the first group study, $5 \%$ kefir grain was added into full fat UHT cow milk. In the second group, E. coli and S. aureus cultures were separately added into the whole milk UHT cow milk to be $10^{5} \mathrm{cfu} \mathrm{mL}^{-1}$ separately with $5 \%$ kefir grain and left to incubate at $22^{\circ} \mathrm{C}$ for 24 hours. During the incubation, 0., 1., 2., 6., 12. and at 24 hours, the samples were taken and analyzed. After fermentation, kefir was washed with sterile distilled water, separated with a plastic sieve and kept in milk at $4{ }^{\circ} \mathrm{C}$.
In the stage II of the study, after Kefir was produced and then the Kefir samples without grains were taken into sterile glass jars. E. coli and S. aureus cultures were separately added to a group of kefir jar in the amount of $10^{5} \mathrm{cfu} \mathrm{mL}^{-1}$ and all the jars were kept at $5{ }^{\circ} \mathrm{C}$ for 3 days. Samples were taken and analyzed on a daily basis. The non-bacterial kefir sample was examined as a control. All the studies were carried out in pair parallel.

\subsection{Microbiological analysis}

Dilutions were prepared from kefir samples and LAB counts were counted on the MRS agar containing 200 ppm cycloheximide and incubated for $24-48$ hours at $35^{\circ} \mathrm{C}$ under $10 \% \mathrm{CO}_{2}$ conditions. After incubation, they were counted, different appearing colonies were purified, and then Gram staining and catalase assay were performed. Yeast was counted on the yeast peptone dextrose agar (YDP) and by incubated at $25^{\circ} \mathrm{C}$ for 48 hours. E.coli was grown on CT-SMAC for 24 hours at $35^{\circ} \mathrm{C}$. The colorless colonies formed on CT-SMAC were evaluated. S. aureus was counted on BP Agar and incubated at $37^{\circ} \mathrm{C}$ for $48 \mathrm{~h}$. The typical black or gray colonies of BP Agar were evaluated as S. aureus (Chapman 2000; Harrigan \& McCance, 1996). The colonies with different appearances were purified and examined under the microscope by Gram staining.

\subsection{Physicochemical analyses}

At each sampling time, the $\mathrm{pH}$ value of Kefir was measured with a HANNA pH meter (HANNA Instruments, Italy). Titratable acidity (TA, lactic acid in percentage) was determined by titration with $0.1 \mathrm{~N} \mathrm{NaOH}$ in the presence of phenolphthalein after mixing $25 \mathrm{~mL}$ of kefir sample with $10 \mathrm{~mL}$ of distilled hot water. Viscosity measurements were performed using a viscometer (Haake Viscotester VT6/7R) at $100 \mathrm{rpm}$.

All physico-chemical analyzes were performed in four replicates.

\section{Results}

The $\mathrm{pH}$ and titratable acidity values of the Kefir samples during the fermentation and storage period were illustrated in Figures 1, 2, 3 and 4. During fermentation, the $\mathrm{pH}$ decreased slowly in all samples (Figure 1). Initially while the $\mathrm{pH}$ was 6 in all samples, it eventually decreased to $\mathrm{pH} 4.5$ and 4.6 at the end of fermentation. During storage, the $\mathrm{pH}$ did not change significantly. The $\mathrm{pH}$ values of kefir were about 4.5 at the end of the storage period (Figure 2). During fermentation, TA\% increased after two hours (Figure 3). During storage, TA\% value remained the same (Figure 4).

The viscosity (measured in $\mathrm{mPa}$ ) values of the kefir samples were illustrated in Table 1 . The viscosity values increased markedly during fermentation. During the storage of kefir, the viscosity increased until $48^{\text {th }}$ hours and then decreased at $72^{\text {nd }}$ hours.

The changes in the lactic acid bacteria, yeast, E. coli and S. aureus numbers in kefir fermentation were illustrated in Figure 5. It was found that the lactic acid bacteria and yeast counts were initially $4.74 \log _{10}$ cfu mL $\mathrm{mL}^{-1}$ and $4.58 \log _{10}$ cfu $\mathrm{mL}^{-1}$, respectively. At the end of the fermentation process, E. coli decreased from 


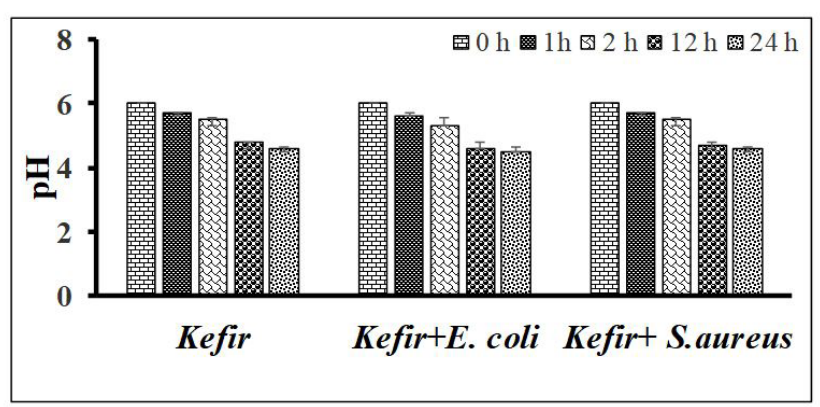

Figure 1. Change of $\mathrm{pH}$ values of kefir during the fermantation.

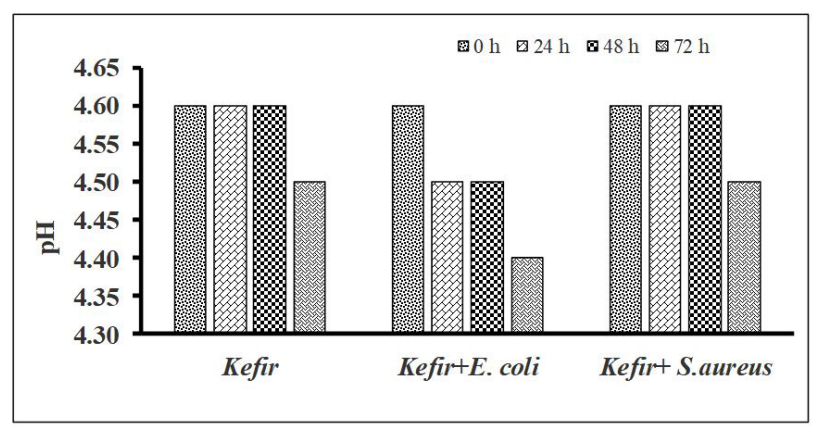

Figure 2. Change of $\mathrm{pH}$ values of kefir during the storage $5{ }^{\circ} \mathrm{C}$.

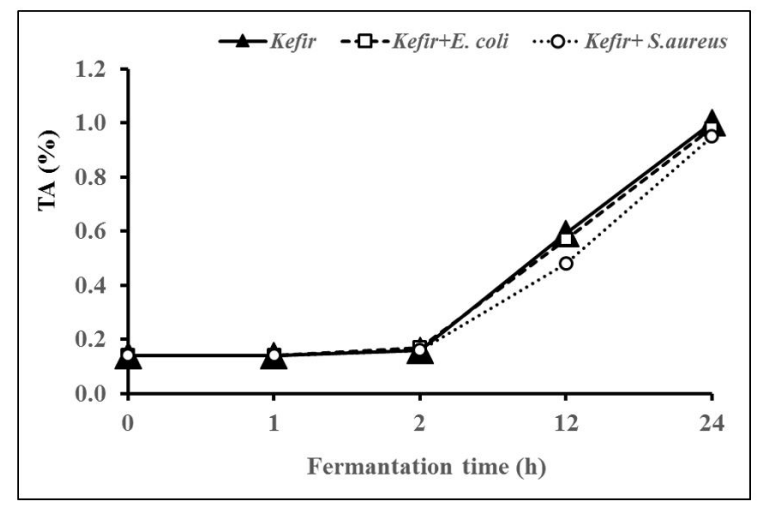

Figure 3. Change of titratable acidity (TA) of kefir during the fermentation.

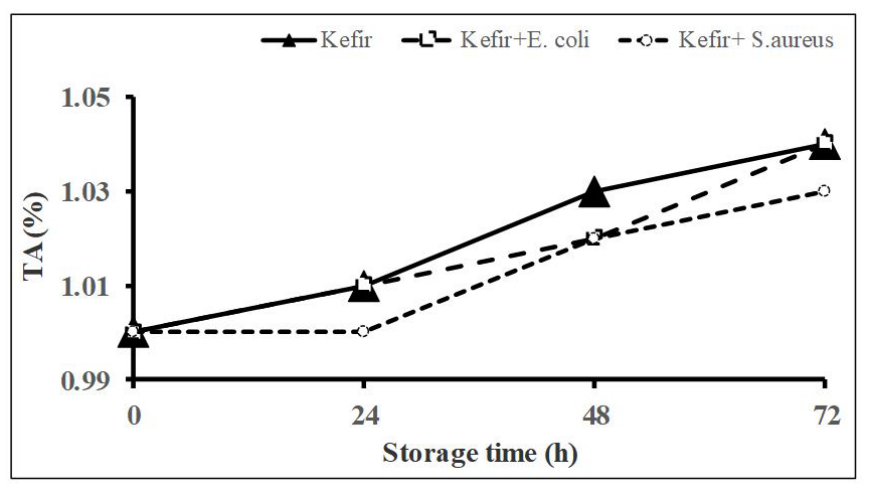

Figure 4. Change of titratable acidity (TA) of kefir during the storage $5^{\circ} \mathrm{C}$.

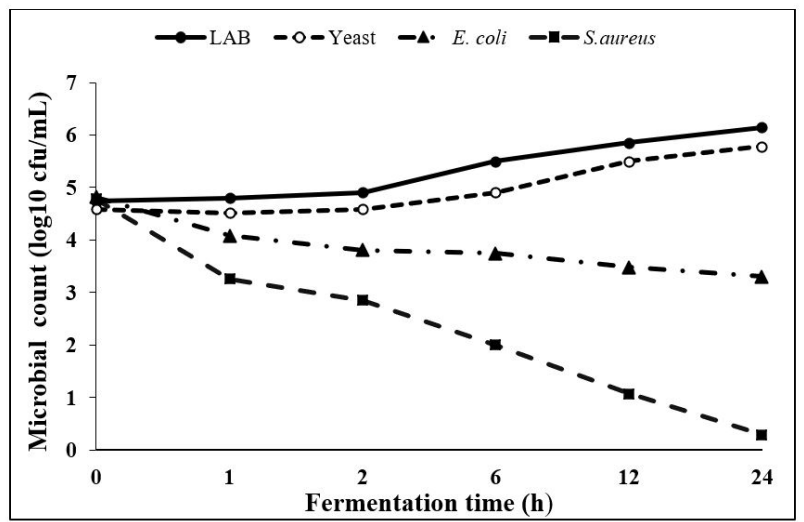

Figure 5. Change of bacteria and yeast count of kefir during the fermentation.

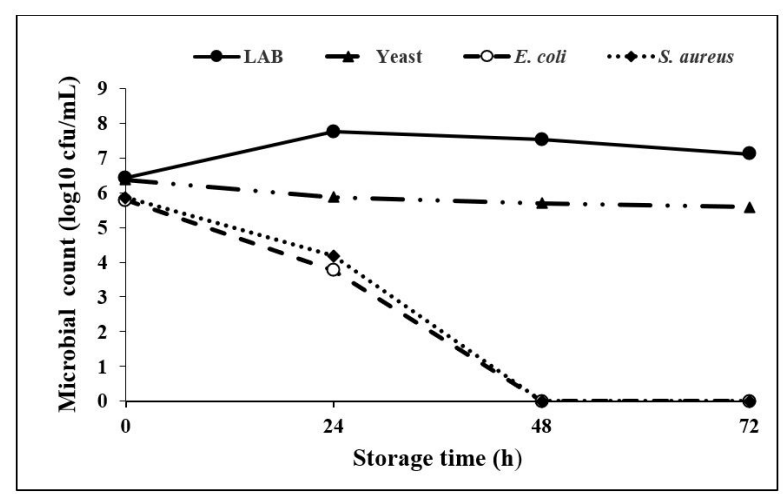

Figure 6. Change of bacteria and yeast count of kefir during the storage $5^{\circ} \mathrm{C}$.

Table 1. Changes in physicochemical values in the kefir samples ( $\mathrm{mPa}$ ).

\begin{tabular}{|c|c|c|c|c|c|c|c|c|c|}
\hline & \multicolumn{5}{|c|}{ Fermantation during $(\mathrm{h})$} & \multicolumn{4}{|c|}{ During the storage $(\mathrm{h})$} \\
\hline & 0 & 1 & 2 & 12 & 24 & 0 & 24 & 48 & 72 \\
\hline $\begin{array}{l}\text { Viscosity } \\
\text { (mPas) }\end{array}$ & 236 & 237 & 243 & 352 & 466 & 467 & 636 & 612 & 598 \\
\hline
\end{tabular}

4.82 $\log _{10}$ cfu mL $\mathrm{m}^{-1}$ to $3.30 \log _{10} \mathrm{cfu} \mathrm{mL}^{-1}$ and S. aureus count decreased from $4.78 \log _{10}$ cfu mL $\mathrm{mL}^{-1}$ to $0.30 \log _{10} \mathrm{cfu} \mathrm{mL}^{-1}$.

During storage, while there was no significant change in yeast and LAB counts, E. coli and S. aureus counts dropped significantly (Figure 6).

\section{Discussion}

During fermentation, the $\mathrm{pH}$ slowly decreased in all kefir samples. Yoo et al. (2013) obtained similar results in the kefir they produced with different methods. The researchers reported that $\mathrm{pH}$ dropped slowly during fermentation. At the end of fermentation, they found that the $\mathrm{pH}$ changed from 3.99 to 4.52 . In all the samples, while TA was initially $0.14 \%$, the fermentation was $1.00 \%$ and $1.01 \%$ in the end. There was no significant difference in bacterial inoculated samples either. Similar results were obtained from Yoo et al. (2013). In another 
study, Özdestan \& Üren (2010) reported that pH values changed between 4.11 and 4.53 in the kefir samples and the TA values varied between $0.65 \%$ and $1.05 \%$.

During storage, the $\mathrm{pH}$ did not change significantly. TA\% value remained the same. Irigoyen et al. (2005) reported that the $\mathrm{pH}$ value of kefir was about 4.5. The fact that TA\% values of kefir did not drop too much during storage could be because the number of lactic acid bacteria did not increase or in fact, decreased slightly during storage. The $\mathrm{pH}$ of kefir may not have changed much due to the yeast in kefir. Collar (1996) found that yeast and lactic acid bacteria produced lactic acid and lactic acid bacteria more slowly than the lactic acid bacteria.

The viscosity values increased markedly during fermentation. During the storage of kefir, viscosity increased until $48^{\text {th }}$ hours and then decreased at $72^{\text {nd }}$ hours. The studies conducted by various researchers reported an increase in viscosity during storage of yoghurt samples (Abrahamsen \& Holmen, 1980). The increase in viscosity of kefir is related to the total solids content of kefir, the degree of hydrolysis of proteins, the exopolysaccharide (EPS) production capacity and acid production capacity of microorganisms in kefir (Tamime \& Robinson, 2007).

During fermentation, the LAB counts increased from 4.74 $\log _{10}$ cfu mL $\mathrm{m}^{-1}$ to $6.44 \log _{10} \mathrm{cfu} \mathrm{mL}^{-1}$ and yeast counts increased from $4.58 \log _{10}$ cfu mL $\mathrm{mL}^{-1}$ to $5.78 \log _{10}$ cfu mL $\mathrm{mL}^{-1}$. Similar to the results of this study, Beukes et al. (2001) reported an average of 8 $\log _{10}$ cfu mL $\mathrm{mL}^{-1} \mathrm{LAB}$ counts in traditional South African fermented milk. Yoo et al. (2013) found that the number of LAB increased during fermentation of kefir, the LAB number increased from 4.29 $\log _{10} \mathrm{cfu} \mathrm{mL} \mathrm{mL}^{-1}$ to $8.52 \log _{10} \mathrm{cfu} \mathrm{mL} \mathrm{L}^{-1}$, and then their development slowed down. These values are higher than those in our study. This difference may be due to differences in experimental conditions such as different fermentation temperatures as well as to the amount of initial culture. Leite et al. (2013) reported that the added culture for kefir increased significantly in the first 12 hours and then reached the value of $7.8 \log _{10} \mathrm{cfu} \mathrm{mL}^{-1}$ in 24 hours. The number of LABs during storage did not change significantly. Similar results were reported in Yoo et al. (2013) as well. Kang et al. (2013) reported that the number of LABs did not change much during storage for 9 days.

During fermentation, the yeast counts increased gradually. The yeast counts did not change during storage. It was reported that the traditional fermented dairy products with a high number of yeasts were related to traditional containers used for the fermentation of dairy products. In South Africa, earthenware pots were reported to contain yeast (Kebede et al., 2007).

While E. coli was not significantly inhibited, $S$. aureus was inhibited at high rates during the fermentation process. In the storage process, pathogen bacteria were inhibited within 2 days. No pathogenic bacteria could be counted on the day 3 of storage.

E. coli was not inhibited during the fermentation process because it was resistant to acidic conditions (Figure 6). However, the number of hydrogen peroxide produced by the LAB dropped. It was found that the most important inhibition effects of $\mathrm{LAB}$ at $5{ }^{\circ} \mathrm{C}$ was hydrogen peroxide produced (Yap \& Gilliland, 2000).
The inhibition of E. coli during storage of kefir may be due to the hydrogen peroxide produced by LAB in kefir. Kivanç \& Yapıcı (2015) reported that the LAB isolated from kefir produced hydrogen peroxide between 0.01 and $0.69 \mathrm{mg} \mathrm{mL}^{-1}$. Similarly, the bacteriocin produced by LAB in the inhibition of $E$. coli or bacteriocin substances may have been effective. In addition, considering that low temperature invigorates E. coli O157: H7 (Clavero \& Beuchat, 1996), its inhibition in 48 hours during storage is important.

Acidic medium as a result of lactic acid fermentation of the $\mathrm{LAB}$ in kefir is one of the most important factors in the inhibition of $S$. aureus and also has inhibitory effect on the LAB-produced hydrogen peroxide S. aureus (Charlier et al., 2009). However, LAB may also have inhibitory properties on $S$. aureus. LAB can also synthesize inhibitory bacteriocin and similar substances on $S$. aureus (Cotter et al., 2005). Kıvanç \& Yapıcı (2015) reported that L. plantarum, Lactobacillus pentosus and Lactobacillus paracasei spp paracasei strains isolated from kefir samples inhibited the neutralized cell-free filtrates of $S$. aureus. The researchers in question reported that lactic acid bacteria isolated from kefir produced lactic acid in $8.68-1.12 \mathrm{mg} \mathrm{mL}^{-1}$ (Kıvanç \& Yapıc1, 2015). The rate of $\mathrm{LAB} / \mathrm{S}$. aureus was effective on the inhibition of S. aureus as well (Charlier et al., 2009).

Dineen et al. (1998) reported that E. coli and S. aureus survived during the yogurt fermentation process and that the presence of these bacteria in yogurt was indicative of a contamination during yogurt production. Farrag (1992) reported that although the acidity and $\mathrm{pH}$ levels of kefir samples were not different, the populations of pathogenic microorganisms in these samples decreased at various levels during storage at low temperatures.

Unlike our findings, Gülmez \& Güven (2003) reported that E. coli O157: $\mathrm{H7}$ survived in the pasteurized kefir and modified kefir for 21 days at $5-7^{\circ} \mathrm{C}$. This may be due to the fact that the natural flora was damaged in the pasteurized and modified kefir. It was reported that food stuffs between the kefir microbes and test strains caused a bacteriostatic effect on E. coli due to competition and / or substances that might be seen in the early stages of milk fermentation (Garrote et al., 2000). Fermentation and storage conditions in fermented dairy products affect the development of pathogenic microorganisms in these products (Ogwaro et al., 2002). In general, Kefir samples have inhibitory effects on E. coli and S. aureus and it was reported that this result may be important since it may be too low after contamination of E. coli and S. aureus infectious dose (Buchanan \& Doyle, 1997).

\section{Conclusion}

The E. coli contamination prior to kefir fermentation may be of importance for the public health. S. aureus contamination, on the other hand, is of no great importance since $S$. aureus is inhibited during the fermentation process. If $S$. aureus and E. coli contamination occurs after fermentation, the bacteria may be inhibited within 48 hours. This is important for postfermentation contamination. Especially if $E$. coli contamination is assumed to be at low concentration, kefir is a safe fermentation drink. However, the production and storage conditions need to be paid attention to. 


\section{Acknowledgements}

This study was supported by Anadolu University. Compliance with ethical standards.

\section{References}

Abrahamsen, R. K., \& Holmen, T. B. (1980). Yoghurt from hyperfiltrated, ultrafiltrated and evaporated milk and from milk with added milk powder. Milchwissenschaft. Milk Science International, 35, 399-402.

Beukes, E. M., Bester, B. H., \& Mostert, J. F. (2001). The microbiology of South African traditional fermented milks. International Journal of Food Microbiology, 63(3), 189-197. http://dx.doi.org/10.1016/ S0168-1605(00)00417-7. PMid:11246902.

Bourrie, B. C. T., Willing, B. P., \& Cotter, P. D. C. (2016). The microbiota and health promoting characteristics of the fermented beverage kefir. Frontiers in Microbiology, 7, 647. http://dx.doi.org/10.3389/ fmicb.2016.00647. PMid:27199969.

Buchanan, R. L., \& Doyle, M. M. (1997). Foodborne disease significance of E. coli O157:H7 and other enter hemorrhagic E. coli. Food Technology, 51, 69-76.

Chapman, P. A. (2000). Methods available for the detection of Escherichia coli $\mathrm{O} 157$ in clinical, food and environmental samples. World Journal of Microbiology \& Biotechnology, 16(8-9), 733-740. http://dx.doi. org/10.1023/A:1008985008240.

Charlier, C., Cretenet, M., Even, S., \& Le Loir, Y. (2009). Interactions between Staphylococcus aureus and lactic acid bacteria: an old story with new perspectives. International Journal of Food Microbiology, 131(1), 30-39. http://dx.doi.org/10.1016/j.ijfoodmicro.2008.06.032. PMid:18687499.

Clavero, M. S., \& Beuchat, L. R. (1996). Survival of E. coli in broth and processed salami as influenced by $\mathrm{pH}$, water activity, and temperature and suitability of media for its recovery. Applied and Environmental Microbiology, 62, 235-2740.

Collar, C. (1996). Biochemical and technological assessment of the metabolism of pure and mixed cultures of yeast and lactic acid bacteria in breadmaking applications. The Journal of Biological Chemistry, 2, 349-367.

Cotter, P. D., Hill, C., \& Ross, R. P. (2005). Bacteriocins: developing innate immunity for food. Nature Reviews. Microbiology, 3(10), 777-788. http://dx.doi.org/10.1038/nrmicro1273. PMid:16205711.

Dineen, S. S., Takeuchi, K., Soudah, J. E., \& Boor, K. J. (1998). Persistence of Escherichia coli O157: H7 in dairy fermentation systems. Journal of Food Protection, 61(12), 1602-1608. http://dx.doi.org/10.4315/0362028X-61.12.1602. PMid:9874336.

Farnworth, E. R., \& Mainville, I. (2003). Kefir: a fermented milk product. In: E. R. Farnworth (Ed.), Handbook of fermented functional foods (p. 77-112). Boca Raton: CRC Press.

Farrag, S. A. (1992). Behavior of Escherichia coli O157:H7 or Yersinia enterocolitica at 4 or $7^{\circ} \mathrm{C}$ in raw milk inoculated with a commercial culture of lactic acid bacteria. Milchwissenschaft. Milk Science International, 47, 149-152.

Finlay, B. B., \& Falkow, S. (1989). Common themes in microbial pathogenicity. Microbiological Reviews, 53(2), 210-230. PMid:2569162.

Garrote, G. I., Abraham, A. G., \& De Antoni, G. L. (2000). Inhibitory power of kefir: The role of organic acids. Journal of Food Protection, 63(3), 364-369. http://dx.doi.org/10.4315/0362-028X-63.3.364. PMid:10716566.

Garrote, G. L., Abraham, A. G., \& De Antoni, G. L. (2001). Chemical and microbiological characterisation of kefir grains. The Journal of Dairy Research, 68(4), 639-652. http://dx.doi.org/10.1017/ S0022029901005210. PMid:11928960.

Gülmez, M., \& Güven, A. (2003). Survival of Escherichia coli O157:H7, Listeria monocytogenes $4 \mathrm{~b}$ and Yersinia enterocolitica $\mathrm{O} 3$ in ayran and modified kefir as pre- and post fermentation contaminant. Vet Med Czech, 48(5), 126-132. http://dx.doi.org/10.17221/5759-VETMED.

Harrigan, W. F., \& McCance, M. E. (1996). Laboratory methods in microbiology (Vol. 65, p. 8-9). London: Academic Press.

Hennekinne, J. A., De Buyser, M. L., \& Dragacci, S. (2012). Staphylococcus aureus and its food poisoning toxins: characterization and outbreak investigation. FEMS Microbiology Reviews, 36(4), 815-836. http:// dx.doi.org/10.1111/j.1574-6976.2011.00311.x. PMid:22091892.

Irigoyen, A., Arana, I., Castiella, M., Torre, P., \& Ibanez, F. C. (2005). Microbiological, physicochemical, and sensory kefir during storage. Food Chemistry, 90(4), 613-620. http://dx.doi.org/10.1016/j. foodchem.2004.04.021.

Jacobsen, C. N., Rosenfeldt Nielsen, V., Hayford, A. E., Møller, P. L., Michaelsen, K. F., Paerregaard, A., Sandström, B., Tvede, M., \& Jakobsen, M. (1999). Screening of probiotic activities of forty-seven strains of Lactobacillus spp. by in vitro techniques and evaluation of the colonization ability of five selected strains in humans. Applied and Environmental Microbiology, 65(11), 4949-4956. PMid:10543808.

Kang, K. M., Park, C. S., \& Lee, S. H. (2013). Effects of Dtagatose on the growth of intestinal microflora and the fermentation of yogurt. J. Korean Soc. Food Sci. Nutr, 42(3), 348-354. http://dx.doi.org/10.3746/ jkfn.2013.42.3.348.

Kebede, A., Viljoen, B. C., Gadaga, T. H., Narvhus, J. A., \& LourensHattingh, A. (2007). The effect of container type on the growth of yeast and lactic acid bacteria during production of Sethemi, South African spontaneously fermented milk. Food Research International, 40(1), 33-38. http://dx.doi.org/10.1016/j.foodres.2006.07.012.

Kim, D.-H., Jeong, D., Kim, H., Kang, I.-B., Chon, J.-W., Song, K.-Y., \& Seo, K.-H. (2016). Antimicrobial activity of kefir against various food pathogens and spoilage bacteria. Korean Journal for Food Science of Animal Resources, 36(6), 787-790. http://dx.doi.org/10.5851/ kosfa.2016.36.6.787. PMid:28115890.

Kıvanç, M., \& Yapıc1, E. (2015). Kefir as a probiotic dairy beverage: determination lactic acid bacteria and yeast. International Journal of Food Engineering, 1, 55-60. http://dx.doi.org/10.18178/ijfe.1.1.55-60.

Le Loir, Y., Baron, F., \& Gautier, M. (2003). Staphylococcus aureus and food poisoning. Genetics and Molecular Research, 2(1), 63-76. PMid:12917803.

Leite, A. M. O., Miguel, M. A., Peixoto, R. S., Rosado, A. S., Silva, J. T., \& Paschoalin, V. M. (2013). Microbiological, technological and therapeutic properties of kefir: a natural probiotic beverage. Brazilian Journal of Microbiology, 44(2), 341-349. http://dx.doi.org/10.1590/ S1517-83822013000200001. PMid:24294220.

Marshall, V. M. (1993). Starter cultures for milk fermentation and their characteristics. International Journal of Dairy Technology, 46(2), 4956. http://dx.doi.org/10.1111/j.1471-0307.1993.tb00860.x.

Mead, P. S., \& Griffin, P. M. (1998). Escherichia coli O157:H7. Lancet, 352(9135), 1207-1212. http://dx.doi.org/10.1016/S0140-6736(98)012677. PMid:9777854.

Ogwaro, B., Gibson, H., Whitehead, M., \& Hill, D. J. (2002). Survival of Escherichia coli $\mathrm{O} 157: \mathrm{H7}$ in traditional African yoghurt fermentation. International Journal of Food Microbiology, 79(1-2), 105-110. http:// dx.doi.org/10.1016/S0168-1605(02)00184-8. PMid:12382690.

Özdestan, Ö., \& Üren, A. (2010). Biogenic amine content of kefir: a fermented dairy product. European Food Research and Technology, 231(1), 101-107. http://dx.doi.org/10.1007/s00217-010-1258-y. 
Prado, M. R., Blandón, L. M., Vandenberghe, L. P., Rodrigues, C., Castro, G. R., Thomaz-Soccol, V., \& Soccol, C. R. (2015). Milk kefir: composition, microbial cultures, biological activities, and related products. Frontiers in Microbiology, 6, 1177. http://dx.doi. org/10.3389/fmicb.2015.01177. PMid:26579086.

Schneedorf, J. M., \& Anfiteatro, D. (2004). Quefir, um probiótico produzido por microorganismos encapsulados e inflamação. In J. C. T. Carvalho (Ed.), Fitoterápicos anti-inflamatórios aspectos químicos, farmacológicose aplicações terapêuticas (Chap. 33, pp. 443-467). Ribeirão Preto: Tecmedd.

Tamarapu, S., McKillip, J. L., \& Drake, M. (2001). Development of a multiplex Polymerase chain reaction assay for detection and differentation of Staphylococcus aureus in dairy products. Journal of Food Protection, 64(5), 664-668. http://dx.doi.org/10.4315/0362028X-64.5.664. PMid:11347997.
Tamime, A. Y., \& Robinson, R. K. (2007). Tamime and Robinson's Yoghurt; science and technology ( $3^{\text {th }}$ ed., pp 348-467). Cambridge: Woodhead Publishing Ltd and CRC Press LLC. http://dx.doi. org/10.1533/9781845692612.348.

Ünal, B. Ü., \& Arslanoğlu, A. (2013). Phylogenetic identification of bacteria within kefir by both culture-dependent and culture-independent methods. African Journal of Microbiological Research, 7(36), 45334538. http://dx.doi.org/10.5897/AJMR2013.6064.

Yap, P. S., \& Gilliland, S. E. (2000). Comparison of newly isolated strains of Lactobacillus delbrueckii subsp. lactis for hydrogen peroxide production at 5 degrees C. Journal of Dairy Science, 83(4), 628-632. http://dx.doi.org/ 10.3168/jds.S0022-0302(00)74922-8.

Yoo, S.-H., Seong, K.-S., \& Yoon, S.-S. (2013). Physicochemical properties of kefir manufactured by a two-step fermentation. Korean J Food Sci An, 33(6), 744-751. http://dx.doi.org/10.5851/kosfa.2013.33.6.744. 